Article

\title{
Coloniality in the German Higher Education System: Implications for Policy and Institutional Practice
}

\author{
Lisa Unangst ${ }^{1, *}$ and Ana M. Martínez Alemán ${ }^{2}$ \\ ${ }^{1}$ Centre for Higher Education Governance Ghent, Ghent University, Belgium; E-Mail: unangstl@bc.edu \\ 2 Department of Educational Leadership and Higher Education, Lynch School of Education and Human Development, \\ Boston College, USA; E-Mail: ana.martinez-aleman@bc.edu \\ * Corresponding author
}

Submitted: 3 February 2021 | Accepted: 16 April 2021 | Published: 21 July 2021

\begin{abstract}
This article focuses on the public German higher education sector as a site upon and through which coloniality is enacted. This status quo indicates exclusionary effects and merits interrogation. We briefly discuss the history of German colonialism to understand how coloniality pervades higher educational structures in the German context today. Two proposals addressing coloniality in German higher education are made: the development of structures centering diverse faculty and the support of ethnic and identity studies.
\end{abstract}

\section{Keywords}

colonialism; coloniality; diversity; Germany; higher education; identity

\section{Issue}

This article is part of the issue "Inclusive Universities in a Globalized World" edited by Liudvika Leišyte (TU Dortmund, Germany), Rosemary Deem (Royal Holloway, UK) and Charikleia Tzanakou (Oxford Brookes University, UK).

(C) 2021 by the authors; licensee Cogitatio (Lisbon, Portugal). This article is licensed under a Creative Commons Attribution 4.0 International License (CC BY).

\section{Introduction}

Coloniality has been described by Grosfoguel (2007, p. 219) as "the continuity of colonial forms of domination after the end of colonial administrations, [which] produced colonial cultures and structures in the modern/colonial capitalist/patriarchal world-system." That is to say, coloniality is an ongoing and pervasive system of hierarchy that persists worldwide, and whose antecedent is the physical occupation of colonialism. Mechanisms of coloniality impact educational structures. Clifford and Montgomery (2017, p. 1149) illustrate that "coloniality still pervades many countries and education systems, and institutional inertia and investment in the status quo fuel resistance to change."

Coloniality lingers not only in sites of colonization, but in colonizing contexts as well (Asher, 2009; Collective People's Knowledge Editorial, 2016). As Migliarini (2018, p. 439) has written of the Italian case, terms and concepts related to race and racism are made prob- lematic by Italy's colonial history, thereby "foreclosing any discussions of race and white privilege in public space." This reflects a relationship between coloniality's structures and institutionalized, nationally specific racism (Friedrich, 2011), as well as European taboos around race-based discourses (Grigolo et al., 2011). As Erel et al. (2016, p. 1341) have noted, "recognition of racism as a structuring feature of European societies is needed to address how Europe's migration regimes articulate and are articulated by racialization and coloniality" (see also Gutiérrez Rodríguez et al., 2010; Lentin, 2014; Mignolo, 2012; Möschel, 2011). These discourses extend to the tertiary education sector as well. Gutiérrez Rodríguez (2016) has addressed this point in her work on the German setting, writing that racial stratification has evolved to reinforce racism and coloniality. She writes that:

Subtle institutional practices [favor] the access of the White national affluent population....Further, as we 
will see in regard to the implementation of migration control policies in universities, while not explicitly operating within a racial matrix, the logic of differentiation that they establish reproduces social hierarchies reflecting and reinforcing processes of racialization. (Gutiérrez Rodríguez, 2016, p. 169)

This article focuses on the largely public German tertiary education sector as a site upon and through which coloniality is enacted, a status quo indicating exclusionary effects and one which merits interrogation. As Pusser and Marginson (2013, p. 552) have written, distinct, nationally specific ideologies frame "creation myths, sagas, and beliefs about national culture that motivate postsecondary policies and assure legitimacy" (see also Meyer \& Rowan, 1977). In the German setting, this also refers to the myth of white German racial and ethnic superiority, which in the context of colonial fantasy can be traced to at least the 18th century as discussed by Susanne Zantop (1997). Indeed, mechanisms for higher education access and student support in Germany are frequently couched in language emphasizing excellence and meritocracy, which are discursive proxies for racial and ethnic hierarchy (Hüther \& Krücken, 2018; Klein, 2016). This argumentation is also familiar in other national contexts (Chong, 2014; Morgan, 2006; Pilz \& Alexander, 2011; Warikoo, 2016; Yao et al., 2018).

In short, we conceive of German public higher education institutions (HEIs) as social institutions of the state-funded by the nation, the federal states and the public - in which the discourse of racial and ethnic superiority (racism) and its discursive expression through curricula and meritocracy circulate to limit educational access and opportunity for disenfranchised racial and ethnic minorities including, but not limited to, migrant groups. The discourse of racism produces the principle of meritocracy and supplies the application of meritocratic systems with discursive power. Consequently, the principle of meritocracy becomes discursive itself, and its systems or mechanisms-e.g., faculty hiring practices, curricular restrictions-distribute power and reify racist regimes. Here, discourse is understood as encompassing systems and structures that, in the case of higher education, frame knowledge exchange and creation. This draws from Bohman's (1999) depiction of research as social process (see also Martínez Alemán, 2014).

We outline how a postcolonial or decolonial lens might be productively applied to the German higher education context and focus on two specific areas. We begin by briefly discussing how coloniality and tertiary education have been considered transnationally, then summarize relevant German colonial history, thereby elucidating how and why Germany is a colonial context. A summary of the German higher education system follows, before we turn to discussion of the barriers to inclusion faced by minoritized faculty in German research universities and Fachhochschulen (universities of applied sciences) alike and posit that the development of degree programs in ethnic and identity studies to help subvert racist curricular discourses is essential. In other words, establishing race and ethnic studies courses and programs can disrupt the racist coloniality of the curriculum, as well as improve access to faculty positions for racially minoritized scholars.

\section{Framing the Interrogation of Coloniality in German Higher Education}

Our consideration of coloniality in German higher education is framed by the work of Edward Said and Homi Bhabha. Decolonial theorists including Quijano, among others, also offer important insights into the practice and contestation of coloniality; both postcolonial and decolonial perspectives "challenge... the insularity of historical narratives and historiographical traditions emanating from Europe" (Bhambra, 2014, p. 115). Despite their relevance, neither postcolonial nor decolonial scholars have been applied extensively to analyses of German education, let alone German tertiary education. For example, in March 2021, a search in the Web of Science database for topics "Edward Said AND German*" produced 27 results, none of which were relevant to higher education. Similarly, a search for "Bhabha AND German*" resulted in 36 matches and a search for "Quijano AND German*" produced one match only, none of which were focused on higher education. This paucity of education scholarship contrasts with the work of activists, historians, and German Studies scholars, who have addressed racist/racialized discourse and its connection to educational practice in Germany. For instance, Peggy Piesche's (2015, p. 224) discussion of Audre Lorde's engagement with "Black antiracist interventions in Germany that were from the start premised on transnationalism" and the benchmark publication Showing our Colors: Afro-German Women Speak Out (Opitz et al., 1992).

Edward Said famously made clear the constructed duality of the Orient/Occident. Said (1978, p. 13) asserted that the "Orient" is but a Western idea in which "tradition of thought, imagery, and vocabulary that have given it reality and presence in and for the West." While his work did not focus on Germany or Germans per se, Said noted an equivalency of that country with other colonial powers, writing that that "what German Orientalism had in common with Anglo, French and later American Orientalism was a kind of intellectual authority over the Orient within Western culture" (Said, 1978, p. 27).

Homi Bhabha $(1994$, pp. 19, 21) has written that "exclusionary imperialist ideologies of self and other" create existential and real-life marginalization, but also produce an opportunity for "cultural and historical hybridity." Further, Bhabha "conceives of Otherness as not only a construction of individuals and groups but a dialogue, a constant navigation of self and other. Hybridity, then, represents a dialectical space for translation of identity, and is fundamentally temporal, a 
'discursive temporality'” (Unangst, 2020, p. 61; see also Bhabha, 1994, p. 25).

This postcolonial perspective makes clear that we ought not to think of individual identity as a binary construct (colonizer: colonized; citizen: alien), but rather changeable hybrids. University constituents, by extension and example, may not be easily categorized as, for example, 'refugee' or 'migrant' in terms of their identities and experiences, though indeed their legal status and attributed social role as such may influence lived experience. Rather, as we see in these cases, identity and its discursive power are fluid. Similarly, ethnic and identity studies program consider hybridity and negotiation as key concepts. Minoritized faculty members and students also encounter hybridity in their experiences of belonging to an academy and yet being excluded from it (in different ways and in different forms; see Avraamidou, 2020).

Bhabha's (1994, p. 22) work also references Foucault's discussion of "repeatable materiality," or the process in which discourse from one entity or institution may be "transcribed in the discourse of another." In the context of tertiary education, this clearly applies to a decentralized system such as Germany's, which is indirectly influenced by national politics and policy, but depends largely on the 'translation' of state-level initiatives and implementation at the institutional level. That is to say that the discourse (or systems and structures) of tertiary education is informed by the discourse of politics. "Similarly, the structures of one university may be adapted by another higher education institution, thereby mimicking power structures and hierarchies" (Unangst, 2020 , p. 62). In fact, Foucault (1982, p. 787) refers to educational institutions as a discursive "block of capacitycommunication-power." Effectively engaging in mimetic isomorphism (DiMaggio \& Powell, 1983), universities may be seen to communicate power structures through their discourses that frequently echo each other.

In the German setting, and with particular reference to the support of marginalized populations, it is recognized that institutional mimetic isomorphism may be accelerated by law. In particular this includes anti-discrimination laws with regard to gender. A common response of German tertiary organizations has been to establish structures within the institution to comply with legal mandates (Hüther \& Krücken, 2018 , p. 145). These institutional structures or units include the Gleichstellungsbüro, present at all public HEIs, which were instituted to support women in the academy (Blome et al., 2013; Löther \& Vollmer, 2014; Schroeter, 2009). Other forms of oppression associated with coloniality, specifically racism and racialization, are addressed in the broadest terms by legislation (Constitution of the Federal Republic of Germany, 1949). However, elaborated regulation targeting entrenched racism and racialization is not as visible at the federal, state, or institutional levels. In fact, the European Commission against Racism and Intolerance (2014, p. 10) observed that "the notion of racism is often interpreted too narrowly in Germany and is linked to organised groups. The racist, and particularly xenophobic, character of some public discourse is still not established clearly enough in public debates."

\section{German Colonialism and Coloniality}

How is the German nation state understood as colonial or vehicle for coloniality? German principalities and Imperial Germany pursued colonial territory throughout the 17th, 18th, 19th and 20th centuries, and by the mid-19th century Germany acquired the fourth largest colonial empire behind Britain, France, and the Netherlands (Conrad, 2013). Outposts were established in Africa, Asia and the Pacific (Berman et al., 2014), and German Imperial troops were responsible for the genocide of the Herero and Nama peoples in present-day Namibia. However, as Kurthen (1995, p. 916) has noted of the former West Germany, the "notion of national homogeneity was not challenged by massive postcolonial remigration movements of persons from former overseas colonies" in the post-1945 period. Instead, Schilling (2015, p. 429) observes of this post-war period that the influence of "former colonialists" in essence "ensured that a positive memory of colonialism was upheld [and] established a near seamless link from colonial paternalism to postwar "development." Both the former East and West engaged in what may be seen as colonial acts (Verber, 2010). In 1972, the former West reached a "cultural agreement" with Senegal to ensure that German would be the first foreign language taught in its public school system (Witte, 2011). Colonial policies affected minoritized groups within Germany as well; writing of the former East, Piesche (2018, p. 229) observes that:

In the GDR's relatively homogeneous and closed society, Blacks were presumed to be exotic, foreign, and different-patterns of attribution similar to those occurring in other countries. To be associated with such attributes meant also to be regarded as part of 'another' society, definitely not part of the GDR but rather foreigners whose stay was limited.

In present day Germany, despite increasing acknowledgment of profound colonial violence, issues around coloniality persist in education and external to it. We now move to discuss the structure of higher education system in that country in order to preface our proposals for change.

\section{German Tertiary Education}

\subsection{System Structure}

In order to understand the function of coloniality in the German higher education sector, it is important to briefly outline the system's present structure. The higher 
education system is both primarily public and decentralized, ceding the direction of higher education to the 16 federal states. Most students in Germany attend university within their state of residence (Spiess \& Wrohlich, 2010), which is important given that the demographics (particularly related to residents of migrant background) vary quite dramatically across the former border of East and West Germany. Consequently, the student bodies at the HEls in question are distinct.

The German system is binary, with universities of applied sciences offering a clear technical or vocational orientation, and research universities including disciplines across the humanities, social sciences, and natural and physical sciences, as well as some professional fields including law (other professional fields associated with the civil service are offered at alternate, specialized institutions; art and musical performance are offered at distinct institutions). Admissions practices differ by both institutional type and field of study; a 'restricted qualification' may be gained by a graduate of certain vocational upper secondary schools to a specific track at universities of applied sciences aligned with their work and study experience (Schindler, 2016). The numerus clausus, an enrollment management technique that admits students to university based on the secondary school leaving exam score (Abitur), applies to almost half of all disciplinary fields in Germany (Finger, 2016).

Historically a relatively 'flat' higher education system in that German research universities were of comparable quality, these institutions are now being intentionally differentiated under the auspices of the German Excellence Initiative, into which billions of Euro continue to be invested in order to facilitate increased competition in terms of admissions, faculty recruitment, and publicprivate collaboration (Bloch et al., 2014; Wolter, 2017). There is concern that the robust support of more 'prestigious' institutions will result in access and equity issues becoming even more urgent (Hüther \& Krücken, 2018). While German universities enrolled a higher proportion of 'non-traditional' students in 2018 than in decades prior, including students with children, part-time students, and others (Middendorff et al., 2013), only 2.4 percent of all enrolled first-year students were classified as part-time in 2013, a signal that there is much progress to be made (Brändle \& Häuberer, 2014). Further, first generation immigrant students display on average a longer time to degree, as well as a higher risk of attrition (Kerst \& Wolter, 2017). In sum, the German tertiary sector may be characterized as highly dynamic and decentralized though increasingly hierarchical, and displaying persistent gaps in terms of student access and success (Unangst, 2020).

\section{Supporting a Diverse Faculty}

Faculty have historically played a powerful role within German HEls. German faculty have been "the heart of the university," and were at one time "all-powerful fig- ures" (Anderson, 2017, p. 3), resulting in a post-1945 system of promotion being established to dissolve relevant forms of exclusion, elitism, and isolation. The current promotion system compels prospective academics to apply for positions at institutions other than where they completed their study. Further, with limited positions at each step of the academic ladder (assistant professor, etc.) competition is fierce for senior positions. While the system purports to rid hiring practices of preferential treatment of internal (and by default, mostly white German) candidates and responds to historical problems of German faculty isolation and elitism, the policy effectively invalidates professional networks built by marginalized groups that would be utilized in the academic job search process. By forcing academic job market candidates to leave the institutions at which they have developed networks, the current system ultimately divests racialized/ethnicized faculty of professional power. A recent German University PhD graduate who self-identified as being from the Global South noted of the academic track that though "in theory" universities had to comply with various hiring laws, "in practice no one can question the institutions which do not implement these guidelines. The white professors can always justify hiring white Germans as their assistants or Habilitanden" (post-docs; Arghavan, 2019, p. 187). Thus, it seems that this structure is unlikely to facilitate the hiring of faculty whose racial/ethnic/migrant identities challenge the norms of the academic profession.

However, the representation of (mostly white) women in the professoriate has risen: The proportion in "Grade A" positions has "more than doubled" over the past 11 years, the period in which equal opportunity offices and support programs centering women have been most active (Hüther \& Krücken, 2018). Additionally, the proportion of women holding chancellorships at public research universities rose from 13 percent to 30 percent between 2008 and 2015, and from 17 to 41 percent at public universities of applied sciences over the same period (Hüther \& Krücken, 2018). These results may be understood as facilitated by the substantial federal and state level support provided to university (Gleichstellungsbüro) for a program referred to as the PWP (Professorinnenprogramm). The PWP that has provided women better access to faculty positions by allocating "substantial funds ( 150 million euros for its 2008-2012 first phase and another 150 million for 2013-2017)" to support professorships for female faculty members at "universities that submit acceptable gender equality plans to an expert committee" (Zippel et al., 2016, p. 877) appointed by the Ministry of Education (BMBF). Further, junior professorships have also been established with the goal of welcoming women to faculty ranks. However, these professorships are still rare and most are non-tenure track (Deutscher Akademischer Austauschdienst, 2018, p. 23).

Reflecting coloniality and the tensions around data collection on ethnicity and race in the German case, 
no authoritative data are available on the racial/ ethnic/migration background of faculty, as national faculty surveys query only gender and no other 'background' questions (Hüther \& Krücken, 2018). However, relatively small-scale surveys have indicated that somewhere between 6 and 9 percent of all German professors (of any level) self-identify a migration background (Neusel \& Wolter, 2016). At present, women comprise less than 20 percent of full professors in Germany (Hüther \& Krücken, 2018), suggesting that German HEls follow the trend in the West in which diversification of the faculty begins with (white) women followed by minoritized men and women (Farrokhzad, 2008; Gasman et al., 2015).

Effectively, structural changes imposed on HEls by federal and state entities have improved the composition of the faculty in terms of gender. By dedicating funds to improve women's opportunities to enter the academic profession, the German government proactively challenged gender discourse. It can be argued, then, that funding can serve as one driver for institutional change; in this example, dulling the edge of discursive sexism. In contrast, targeted and well-funded state and federal programs supporting and improving faculty racial and ethnic diversity are few and far between. As Leichsenring (2011, p. 53) has observed, "at the moment," without state and federal mandates and funding for structural change to improve racial/ethnic diversity, German universities "are very much on their own" in this area. Recently, though some faculty jobs have been posted noting a preference for applicants from migration backgrounds, this appears to be a decentralized, institution-specific effort. Given that the vast majority of tertiary programs in Germany are public and conducted through only a few hundred HEls (German Rectors' Conference, 2021; Salmi, 2000), system-wide initiatives to promote a more diverse faculty are achievable and necessary (Langholz, 2013). Existing efforts to support an increase in the number of female faculty can serve as a model for funding and program development to recruit and promote faculty of migration and other minoritized backgrounds.

It should be noted that programming for increasing the number of women faculty is fueled by social, cultural and political forces that challenge mainstream consciousness. For example, the integration of feminist consciousness and epistemologies into scholarship and the curriculum is often a reflection of discursive challenges to societal norms. A notable example is the case of women's and gender studies in the curriculum of US HEIs that served to alter academic epistemologies/knowledge paradigms and challenge disciplinary canons. Fueled by the rise in feminist consciousness in the 1970s, the development of gender and women's studies programs' 'new knowledges' quickened institutional change to address gender inequities in faculty recruitment, hiring, and promotion (Glazer-Raymo, 2001; Martínez Alemán, 2014). In turn, academic departments can serve as incubators for action, participatory, emancipatory, or decolonial research (Weber, 2016). However, it is important to note that affirmative action in the US setting has tended to benefit white women; there is increasing recognition within US higher education that an intersectional lens is indicated in order to contest continued and pervasive exclusionary hierarchies and support, in particular, Women of Color (Crenshaw, 1991).

\section{University Curricula: Ethnic and Identity Studies Departments}

Coloniality imbues a primarily public tertiary education sector such as Germany's with exclusionary practices consistent with racist and ethnocentric discourses. In this context, identity and power take on important relevance to the institution and for individuals. 'Identity' here refers not only to the fluid self-conceptions of tertiary faculty, staff, and students, but also to identity as social construct and indicator of (possible) lived experiences of discrimination (Nasser, 2019; Wilkins, 2014). Further, it refers to national and institutional identity, which combine in unique and ever-changing ways to influence institutional discourses.

The case for the decolonization of the university curriculum has been made across many national contexts, at the heart of which is an argument for an acknowledgment that curricula are discourses. As discourses, curricula are (as Foucault asserted) "procedures of exclusion" (Peters \& Jandrić, 2018, p. 166) that are marked by the absence of knowledge and subjectivities, and that serve to maintain dominant power relations. Language and practices are expressions linked to knowledge in this scheme, suggesting that what is known and not known, who is known and not known, is an expression of value and validity. As discourse, the university curriculum is a codified expression of knowledge that is valued (if not revered) in society, and by extension, should be reproduced.

A reflection of dominant expressions, beliefs, prevailing norms, and sanctioned politics, a university's curriculum is an expression of the coaction of the accepted narratives of historical context and their sanctioned interpretations. For example, Coate's (2006) diagnosis of the UK's gendered discourse in university curriculum reveals how academic knowledge is an interplay of sociopolitical power relations and the organization and history of the higher education system. The decolonization of the university curricula is not uncommon. Scholars have argued for the decolonization of African university curricula (e.g., Knight, 2018; Winberg \& Winberg, 2017), and have made the case for a decolonization of the Australian university curriculum based on the exclusion and erasure of Indigenous knowledge and perspectives (e.g., McLaughlin \& Whatman, 2011). Lewis (2018) broadens the call by considering the epistemological challenges brought to the university curriculum when we engage the fact of Black diaspora through colonization. In the 
US, ethnic and cultural studies as well as women's and gender studies in the university served to contest the discourse of exclusion and hegemony in university curricula. While there is a nascent literature on the topic in the German sphere, this remains an emerging area of research not only in Germany but in other former colonial states of Western Europe (Colak et al., 2020).

The need for the decolonization of the university curriculum is perhaps especially apparent in the German setting given that the research university has historically occupied a position of power within German society as a whole (Euros, 2016; Phillips, 2016; Tsvetkova, 2014). In the post-1945 period, for example, the German "university was still a 'centre of national identification,' especially for the educated middle class that dominated public life" (Östling, 2016, p. 388). However, that esteemed status belied the purging of racialized students only years before: "By 1937, there were only 500 Chinese students nation-wide, though Berlin alone had registered 1000 Chinese students in 1923....Further, this group was subject to the 'Central Office for Chinese' founded in 1938 by Richard Heydrich to sharply control visas" (Unangst, 2020, p. 30; see also Ha et al., 2007).

Based on the 2012 census of families with a migration history living in Germany, 17 percent have an Asian background and 4 percent an African background (Henkel et al., 2016). These figures do not include foreign nationals who may identify as Afro- or Asian-German. Given Germany's colonial history in most regions worldwide, attention within the university's academic units to the epistemologies that enable the examination of colonial identities and knowledges seems urgently called for. As Maldonado-Torres (2011, p. 4) has noted, ethnic and women's studies departments have enabled "necessary explorations and experimentations that go beyond the strict and largely self-imposed disciplinary and Eurocentric limits" of the Western curriculum that relate to nativist logic of colonial identity.

Using the German Rectors' Conference (2021) database, which is an authoritative source allowing prospective students to search study courses across private, public, and religious institutions and spanning all federal states, we conducted a keyword search to discern to what extent current academic offerings relate to identity studies and diversity in the German context (see Table 1). Of the 20,732 programs included in the database, we found that while there are regional studies programs focused on Asia and Africa (German Rectors' Conference, 2021), there are no programs in place focused on Afro-German Studies or Asian-German Studies at German HEls. Here, we refer to interdisciplinary programs (comparable to African American Studies or Native American Studies) that draw from history, culture, political science, literature, and sociology, among other fields. This relative inattention to Afro-German and Asian-German literature and culture in curricula occurs in spite of a colonial history on the continents. Further, the incorporation of Afro-German literature into German Studies curricula has been identified as slow and insufficient (Johnson, 2001). Calls to include works by Afro-German authors are largely ignored and most HEI curricula lack a systematic incorporation of texts by Afro-Germans (Schenker \& Munro, 2013). In addition, a search for "mobilität" (mobility) resulted in 143 program matches, though the vast majority were engineering and technology-related. Searches for "intercultural" and "interkulturell" also pointed to many programs related to business rather than ethnic or identity studies. All to suggest that coloniality continues to guide German HEI curricula.

Stein $(2018$, p. 150) has suggested that an epistemologically orienting question for educationalists might be "whose voices are centered in curriculum, and whose are absent?" Such an interrogation indicates (among other things) the importance of identity studies departments within existing Western HEls. Much like women's and gender studies has done, these units may approach "reform from within" in pursuit of a decolonized university (Tamdgidi, 2012). Their curricula may center absent voices of the marginalized or subaltern, and simultaneously explore the epistemology of difference supported by the university. Further, these units may serve as catalysts and coactive forces for political advocacy and action, though indeed there is also danger that the formation of identity studies departments may redirect energy towards normative academic goals and away from such advocacy (Glass et al., 2018). Finally, ethnic and identity studies units may serve as generators of new methods and methodologies and as multipliers of related work. Germany's contemporary HEls manifest their own hierarchies of privilege that inevitably relate to temporallybound discourses of 'equal opportunity' and 'diversity' in their curriculum.

\section{Conclusion}

Critique of coloniality is emergent in the German sphere. To this point, referencing the work of Dietze et al. (2007), Boatca (2012, p. 27) has written that:

For Germany's critical intellectuals, having (virtually) no academic curricula dealing with social differences from the perspective of the subalterns' emancipatory claims, represents not only a regrettable German Sonderweg, or special path, in comparison to other Western European settings such as the British or Scandinavian context, but also, and especially, a temporal and financial lag with respect to US American academia.

The decomposition of coloniality in higher education is particularly urgent given the increasing differentiation of the higher education sector in Germany, facilitated by the German Excellence Initiative and implementation of Bologna reforms. Increased differentiation indicates increased selectivity at more prestigious HEls, which is 
Table 1. Existing degree courses related to identity studies at public universities in Germany.

\begin{tabular}{|c|c|c|}
\hline Searched Term & No. Results & Sample Program Titles \\
\hline Afro & 1 & Cultural and Social Anthropology \\
\hline Afrika & 34 & $\begin{array}{l}\text { African Languages and Cultures; African Studies; German as a Second Language in } \\
\text { German-African Contexts; Art History of Africa; History; International Area } \\
\text { Studies; Linguistics }\end{array}$ \\
\hline Asiatisch (Asian) & 32 & Archeology, Buddhist Studies, International Area Studies \\
\hline Black & 0 & \\
\hline Diversity & 41 & $\begin{array}{l}\text { Biodiversity and Conservation; Gender and Diversity; Leading Diversity (in-service } \\
\text { training at Helmut-Schmidt-University/University of the Army Hamburg); } \\
\text { Intercultural Conflict Management; International Business Administration }\end{array}$ \\
\hline Diversität (diversity) & 68 & $\begin{array}{l}\text { Biodiversity and Ecology; Diversity and Inclusion; Diversity Management, Religion } \\
\text { and Education; Empowerment Studies; Physical Geography; Sociology: Diversity } \\
\text { and Society; Sustainable Agriculture }\end{array}$ \\
\hline Ethnische (Ethnic) & 2 & Education; International Migration and Intercultural Relations \\
\hline Ethnizität (Ethnicity) & 2 & Health and Diversity; Social-Cultural Studies \\
\hline Frauen (women) & 13 & $\begin{array}{l}\text { Mechanical Engineering (women's degree course); International women's degree } \\
\text { course in Computer Science }\end{array}$ \\
\hline Gender & 67 & $\begin{array}{l}\text { Advanced Anglophone Studies; Gender Studies; Business Psychology; Health } \\
\text { and Society; Gender and Diversity Studies }\end{array}$ \\
\hline Identity & 4 & Communication Design; Visual and Experience Design \\
\hline Identität (identity) & 4 & Religion and Politics; Spanish Culture and European Identity \\
\hline Intercultural & 42 & $\begin{array}{l}\text { Engineering Management; Intercultural Anglophone Studies; Intercultural } \\
\text { Business Psychology; International Agribusiness; Software Engineering } \\
\text { and Management }\end{array}$ \\
\hline Interkulturell & 214 & $\begin{array}{l}\text { European Studies; French Cultural Studies and Intercultural Communication; } \\
\text { Globalization, Governance, and Law; New Media and Intercultural } \\
\text { Communication; Translation }\end{array}$ \\
\hline Migranten (Migrants) & 3 & Intercultural Conflict Management; Flight, Migration, Society; Social Work \\
\hline Mobilität (Mobility) & 143 & $\begin{array}{l}\text { Automobile and Mobility Management; Logistics, Infrastructure, and Mobility; } \\
\text { Electrical Power and Machine Engineering; International Tourism and Event } \\
\text { Management; Cultural Anthropoligy and European Ethnology; Trans-cultural } \\
\text { Studies }\end{array}$ \\
\hline Queer & 3 & Gender and Queer Studies \\
\hline Rassismus (racism) & 1 & Social Work \\
\hline Schwarz (Black) & 0 & \\
\hline Vielfalt (diversity) & 17 & $\begin{array}{l}\text { Health and Diversity; Pedagogy of Diversity (certificate program for teachers in } \\
\text { training); Linguistic Diversity: Linguistics of anglophone, Baltic, Finnish, } \\
\text { Scandinavian and Slavic cultures }\end{array}$ \\
\hline
\end{tabular}

Source: Assembled by the authors based on German Rectors' Conference (2021).

very likely to further marginalize students less favored by coloniality's hierarchies (Hüther \& Krücken, 2018) that include women, migrants, refugees, LGBTQ+ students and others (Grosfoguel et al., 2015).

By no means does this article present an exhaustive catalog of equity issues in German higher educa- tion to which postcolonial attention is indicated. We propose here initial steps towards applying a postcolonial frame to Germany's tertiary sphere, acknowledging that various bureaucratic and institutional specificities will inevitably challenge the implementation of interventions suggested in these pages. 
However, as we have sought to demonstrate, there is clear evidence that comprehensive, nationally-scoped programs supporting diversity measures (specifically, the equal opportunity of women in academia) have had success in the German setting. Indeed, they represent accepted practice, and it is upon these initiatives that we propose expanding. In order to move towards a liberation of German higher education from coloniality and to effect equitable policies and practice, stakeholders should engage in focused attention to relevant research and policy work in the public and private domains alike. At stake is no less than the equitable support of present and future scholars in an increasingly diverse national context-one which may offer lessons to similar cases worldwide.

\section{Acknowledgments}

We are grateful for the support of the Boston College Open Access Publishing Fund. The authors have gained no financial benefit from the research discussed in this article.

\section{Conflict of Interests}

The authors declare no conflict of interests.

\section{References}

Anderson, R. D. (2017). The German (Humboldtian) university tradition. In J. Shin \& P. Teixeira (Eds.), Encyclopedia of international higher education systems and institutions. Springer. https://doi.org/10.1007/ 978-94-017-9553-1_4-1

Arghavan, M. (2019). The migrant scholar of color as refugee in the Western academy. In M. Arghavan, N. Hirschfelder, L. Kopp, \& K. Motyl (Eds.), Who can speak and who is heard/hurt? Facing problems of race, racism, and ethnic diversity in the humanities in Germany (pp. 177-193). transcript Verlag.

Asher, N. (2009). Decolonization and education: Locating pedagogy and self at the interstices in global times. In R. Coloma (Ed.), Postcolonial challenges in education (pp. 67-77). Peter Lang.

Avraamidou, L. (2020). "I am a young immigrant woman doing physics and on top of that I am Muslim": Identities, intersections, and negotiations. Journal of Research in Science Teaching, 57(3), 311-341.

Berman, N., Mühlhahn, K., \& Nganang, P. (2014). Introduction. In N. Berman, K. Mühlhahn, \& P. Nganang (Eds.), German colonialism revisited (pp. 1-28). University of Michigan Press. https://www.jstor.org/ stable/10.3998/mpub.5034425.3

Bhabha, H. K. (1994). The location of culture (1st ed.). Routledge.

Bhambra, G. K. (2014). Postcolonial and decolonial dialogues. Postcolonial Studies, 17(2), 115-121. https:// doi.org/10.1080/13688790.2014.966414
Bloch, R., Kreckel, R., Mitterle, A., \& Stock, M. (2014). Stratifikationen im Bereich der Hochschulbildung in Deutschland [Stratification in the higher education sector in Germany]. Zeitschrift Fur Erziehungswissenschaft, 17(3), 243-261. https://doi.org/10.1007/ s11618-014-0531-4

Blome, E., Erfmeier, A., Guelcher, N., \& Smykalla, S. (2013). Handbuch Zur Gleichstellungspolitik an Hochschulen [Handbook of equal opportunity politics at higher education institutions]. Springer.

Boatca, M. (2012). Catching up with the (new) west: The German 'excellence initiative,' area studies, and the re-production of inequality. Human Architecture: Journal of the Sociology of Self-Knowledge, 1, 17-30.

Bohman, J. (1999). Theories, practices, and pluralism: A pragmatic interpretation of critical social sciences. Philosophy of the Social Sciences, 29(4), 459-480.

Brändle, T., \& Häuberer, J. (2014). Social capital of nontraditional students at a German university. Do traditional and non-traditional students access different social resources? International Journal of Higher Education, 4(1), 92-105. https://doi.org/10.5430/ijhe. v4n1p92

Chong, T. (2014). Vocational education in Singapore: Meritocracy and hidden narratives. Discourse, 35(5), 637-48. https://doi.org/10.1080/01596306. 2014.927165

Clifford, V., \& Montgomery, C. (2017). Designing an internationationalised curriculum for higher education: Embracing the local and the global citizen. Higher Education Research and Development, 36(6), 1138-1151. https://doi.org/10.1080/07294360. 2017.1296413

Coate, K. (2006). Imagining women in the curriculum: The transgressive impossibility of women's studies. Studies in Higher Education, 31(4), 407-421.

Colak, F. Z., Van Praag, L., \& Nicaies, I. (2020). 'Oh, this is really great work-especially for a Turk': A critical race theory analysis of Turkish Belgian students' discrimination experiences. Race Ethnicity and Education. Advance online publication. https://doi.org/ 10.1080/13613324.2020.1842351

Collective People's Knowledge Editorial. (2016). People's knowledge and participatory action research: Escaping the white-walled labyrinth. Practical Action Publishing. https://doi.org/10.3362/9781780449395

Conrad, S. (2013). Rethinking German colonialism in a global age. Journal of Imperial and Commonwealth History, 41(4), 543-566. https://doi.org/ 10.1080/03086534.2013.836352

Constitution of the Federal Republic of Germany, 1949, last updated through Art. $1 \mathrm{G}$ v. 15.11.2019 I 1546, 1.

Crenshaw, K. (1991). Mapping the margins: Intersectionality, identity politics, and violence against women of color. Stanford Law Review, 43(6), 1241-1299. http://www.jstor.org/stable/1229039

Deutscher Akademischer Austauschdienst. (2018). Annotated charts on Germany's higher education 
and research system. Bonn. https://doi.org/10.3278/ 6004695w

Dietze, G., Hornscheidt, A., Palm, K., \& Walgenbach, K. (2007). Einleitung [Introduction]. In K. Walgenbach, G. Dietze, L. Hornscheidt, \& K. Palm (Eds.), Gender als interdependente Kategorie. Neue Perspektiven auf Intersektionalität, Diversität und Heterogenität [Gender as interdependent category. New perspectives on intersectionality, diversity and heterogeneity] (pp. 7-22). Barbara Budrich.

DiMaggio, P. J., \& Powell, W. W. (1983). The iron cage revisited: Institutional isomorphism and collective rationality in organizational fields. American Sociological Review, 48(2), 147-160.

Erel, U., Murji, K., \& Nahaboo, Z. (2016). Understanding the contemporary race-migration nexus. Ethnic and Racial Studies, 39(8), 1339-1360. https://doi.org/ 10.1080/01419870.2016.1161808

European Commission against Racism and Intolerance. (2014). ECRI report on Germany (fifth monitoring cycle). ECRI. http://www.coe.int/t/dghl/monitoring/ ecri/Country-by-country/Germany/DEU-CbC-V2014-002-ENG.pdf

Euros, G. (2016). The post-war British re-education policy for German universities and its application at the Universities of Goettingen and Cologne (1945-1947). Research in Comparative and International Education, 11(3), 247-266. https://doi.org/ $10.1177 / 1745499916664465$

Farrokhzad, S. (2008). Erfahrungen, Strategien und Potenziale von Akademikerinnen mit Migrationshintergrund [Experiences, strategies, and potential of academics with migration backgrounds]. In G. Hentges, V. Hinnenkamp, \& A. Zwengel (Eds.), Migrations- und Integrationsforschung in Der Diskussion. Biografie, Sprache Und Bildung Als Zentrale Bezugspunkte [Migration and integration research in discussion. Biography, language and education as central points of reference] (pp. 303-322). Verlag fuer Sozialwissenschaften.

Finger, C. (2016). Institutional constraints and the translation of college aspirations into intentions: Evidence from a factorial survey. Research in Social Stratification and Mobility, 46, 112-128. https://doi.org/ 10.1016/j.rssm.2016.08.001

Foucault, M. (1982). The subject and power. Critical Inquiry, 8(4), 777-795.

Friedrich, S. (2011). Rassismus in Der Leistungsgesellschaft [Racism in the meritocracy]. In S. Friedrich (Ed.), Rassismus in Der Leistungsgesellschaft: Analysen und Kritische Perspektiven Zu Den Rassistischen Normalisierungsprozessen Der "Sarrazindebatte" [Racism in the meritocracy: Analyses and critical perspectives on the racist processes of normalization of the "Sarrazin debate"] (pp. 8-39). edition assemblage.

Gasman, M., Abiola, U., \& Travers, C. (2015). Diversity and senior leadership at elite institutions of higher education. Journal of Diversity in Higher Education, 8(1), 1-14. https://doi.org/10.1037/a0038872

German Rectors' Conference. (2021). Higher education institutions in Germany. Higher Education Compass. https://www.hochschulkompass.de/en/highereducation-institutions.html

Glass, R. D., Morton, J. M., King, J. E., Krueger-Henney, P., Moses, M. S., Sabati, S., \& Richardson, T. (2018). The ethical stakes of collaborative communitybased social science research. Urban Education, 53(4), 503-531. https://doi.org/10.1177/00420859 18762522

Glazer-Raymo, J. (2001). Shattering the myths: Women in academe. Johns Hopkins University Press.

Grigolo, M., Hermanin, C., \& Möschel, M. (2011). Introduction: How does race 'count' in fighting discrimination in Europe? Ethnic and Racial Studies, 34(10), 1635-1647. https://doi.org/10.1080/ 01419870.2011 .559263

Grosfoguel, R. (2007). The epistemic decolonial turn: Beyond political-economy paradigms. Cultural Studies, 21(2/3), 211-223. https://doi.org/10.1080/ 09502380601162514

Grosfoguel, R., Oso, L., \& Christou, A. (2015). 'Racism,' intersectionality and migration studies: Framing some theoretical reflections. Identities, 22(6), 635-652. https://doi.org/10.1080/1070289X.2014. 950974

Gutiérrez Rodríguez, E. (2016). Sensing dispossession: Women and gender studies between institutional racism and migration control policies in the neoliberal university. Women's Studies International Forum, 54, 167-177. https://doi.org/10.1016/ j.wsif.2015.06.013

Gutiérrez Rodríguez, E., Boatca, M., \& Costa, S. (2010). Introduction-Decolonizing European sociology: Different paths towards a pending project. In E. Gutiérrez Rodríguez, M. Boatca, \& S. Costa (Eds.), Decolonizing European sociology: Transdisciplinary approaches (pp. 1-13). Ashgate.

Ha, K. N., Al-Samarai, N. L., \& Mysorekar, S. (Eds.). (2007). Chinesische Praesenzen in Deutschland bis 1945 [Chinese presence in Germany through 1945]. In N. L. al-Samarai, K. Nghi-Ha, \& S. Mysorekar (Eds.), Re/Visionen: Postkoloniale Perspektiven von People of Color auf Rassismus, Kulturpolitik und Widerstand in Deutschland [Re/visions: Postcolonial perspectives of people of color on racism, cultural politics, and resistance in Germany] (pp. 171-176). Unrast Verlag.

Henkel, M., Steidle, H., Braukmann, J., \& Sommer, I. (2016). Familien Mit Migrationshintergrund: Analysen Zur Lebenssituation, Erwerbsbeteiligung und Vereinbarkeit von Familie und Beruf [Families with migration background: Analysis of life circumstances, labor market participation and the unity of family and career]. Federal Ministry of Family Affairs.

Hüther, O., \& Krücken, G. (2018). Higher education in Germany: Recent developments in an international 
perspective. Springer. https://doi.org/10.1007/9783-319-61479-3

Johnson, C. (2001). Heimat Deutschland: An examination of Afro-German marginalization [Unpublished doctoral dissertation]. University of Georgia.

Kerst, C., \& Wolter, A. (2017). Die Vielfalt der Studierenden mit Migrationshuntergrund-Ein empirischer Beitrag [The diversity of students with migration background-An empirical contribution]. In A. Neusel \& A. Wolter (Eds.), Mobile Wissenschaft: Internationale Mobilitaet und Migration in der Hochschule [Mobile science: International mobility and migration in higher education] (pp. 245-268). Campus Verlag.

Klein, U. (2016). Gender equality and diversity politics in higher education: Conflicts, challenges and requirements for collaboration. Women's Studies International Forum, 54, 147-156. https://doi.org/10.1016/ j.wsif.2015.06.017

Knight, J. (2018). Decolonizing and transforming the Geography undergraduate curriculum in South Africa. South African Geographical Journal, 100(3), 271-290.

Kurthen, H. (1995). Germany at the crossroads: National identity and the challenges of immigration. The International Migration Review, 29(4), 914-938. https:// doi.org/10.2307/329124

Langholz, M. (2013). The management of diversity in U.S. and German higher education. Management Revue, 25(3), 207-226. https://doi.org/10.1688/ mrev-2014-03-Langholz

Leichsenring, H. (2011). Diversity in German higher education and an economic rationale for equity. Widening Participation and Lifelong Learning, 13(1), 39-56.

Lentin, A. (2014). Postracial silences: The othering of race in Europe. In W. D. Hund \& A. Lentin (Eds.), Racism and sociology (pp. 69-104). Lit Verlag.

Lewis, G. (2018). 'Of becoming and disturbanceone final offering': Some thoughts on familiar stranger: A life between two islands by Stuart Hall. Identities, 25(1), 41-48. https://doi.org/10.1080/ 1070289X.2017.1412156

Löther, A., \& Vollmer, L. (2014). Erfolge Durch Strukturen? Hochschulische Gleichstellungsarbeit Im Wandel [Success through structures? University equal opportunity work in transition]. In A. Löther \& L. Vollmer (Eds.), Gleichstellungsarbeit an Hochschulen: Neue Strukturen-Neue Kompetenzen [Equal opportunity work at universities: New strutures-new competencies] (pp. 15-56). Barbara Budrich.

Maldonado-Torres, N. (2011). Thinking through the decolonial turn: Post-continental interventions in theory, philosophy, and critique-An introduction. TRANSMODERNITY: Journal of Peripheral Cultural Production of the Luso-Hispanic World, 1(2). https:// escholarship.org/uc/item/59w8j02x

Martínez Alemán, A. M. (2014). Managerialism as the "new" discursive masculinity in the university. Fem- inist Formations, 26(2), 107-134.

McLaughlin, J. M., \& Whatman, S. L. (2011). The potential of critical race theory in decolonising university curricula. Asia Pacific Journal of Education, 31(4), 365-377.

Meyer, J. W., \& Rowan, B. (1977). Institutionalized organizations: Formal structure as myth and ceremony. American Journal of Sociology, 83, 340-363.

Middendorff, E., Apolinarski, B., Poskowsky, J., Kandulla, M., \& Netz, N. (2013). Die wirtschaftliche und soziale Lage der Studierenden in Deutschland 2012: 20 [The economic and social situation of students in Germany 2012: 20]. Bildungsministerium fuer Bildung und Forschung.

Migliarini, V. (2018). 'Colour-evasiveness' and racism without race: The disablement of asylum-seeking children at the edge of fortress Europe. Race Ethnicity and Education, 21(4), 438-457. https://doi.org/ 10.1080/13613324.2017.1417252

Mignolo, W. (2012). Local histories/global designs. Coloniality, subaltern knowledges and borderthinking. Princeton University Press.

Morgan, G. (2006). Memory and marginalisationAboriginality and education in the assimilation era. Australian Journal of Education, 50(1), 40-49.

Möschel, M. (2011). Race in mainland European legal analysis: Towards a European critical race theory. Ethnic and Racial Studies, 34(10), 1648-1664. https:// doi.org/10.1080/01419870.2011.566623

Nasser, R. (2019). Identity beyond borders: National identity and the post-colonial alternative. Social Semiotics, 29(2), 145-171. https://doi.org/10.1080/ 10350330.2018.1425317

Neusel, A., \& Wolter, A. (2016). Auf Dem Weg zur Transnationalität? Eine Explorative Studie Transnationalität? Eine Explorative Studie Über Professorinnen und Professoren mit Migrationsbiographie an Deutschen Hochschulen [On the path to transnationality? An explorative study of transnationality? An exploratory study of professors with migrant biographies at German universities]. Das Hochschulwesen, 1, 42-54.

Opitz, M., Oguntoye, K., \& Schultz, D. (1992). Showing our colors: Afro-German women speak out. University of Massachusetts Press.

Östling, J. (2016). The swansong of the Mandarins: Humboldt's idea of the university in early post-war Germany. Modern Intellectual History, 13(2), 387-415. https://doi.org/10.1017/S1479244314000808

Peters, M. A., \& Jandrić, P. (2018). Discourse, genre and curriculum. Open Review of Educational Research, 5(1), 164-178.

Phillips, D. (2016). Investigating education in Germany: Historical studies from a British perspective. Routledge.

Piesche, P. (2015). Inscribing the past, anticipating the future: Audre Lorde and the Black Women's Movement in Germany. In S. Bolaki \& S. Broeck (Eds.), 
Audre Lorde's transnational legacies (pp. 222-225). University of Massachusetts Press.

Piesche, P. (2018). Making African diasporic pasts possible: A retrospective view of the GDR and its Black (step-) children. In S. Lennox (Ed.), Remapping Black Germany: New perspectives on Afro-German history, politics, and culture (pp. 226-242). University of Massachusetts Press. https://doi.org/10.2307/ j.ctv3t5qph.15

Pilz, M., \& Alexander, P. J. (2011). The transition from education to employment in the context of stratification in Japan-A view from the outside. Comparative Education, 47(2), 265-280. https://doi.org/10.1080/ 03050068.2011 .555115

Pusser, B., \& Marginson, S. (2013). University rankings in critical perspective. The Journal of Higher Education, 84(4), 544-568. https://doi.org/10.1353/jhe. 2013.0022

Said, E. W. (1978). Orientalism. Routledge and Kegan Paul.

Salmi, J. (2000). Tertiary education in the twenty-first century challenges and opportunities. World Bank. http://documents1.worldbank.org/curated/en/ 827711468337881262/pdf/324370Tertiary0 EducationOLCSHD062.pdf

Schenker, T., \& Munro, R. (2013). "But You Are Not German": Afro-German culture and literature in the German language classroom. Die Unterrichtspraxis/Teaching German, 2008, 172-185.

Schilling, B. (2015). German postcolonialism in four dimensions: A historical perspective. Postcolonial Studies, 18(4), 427-439. https://doi.org/10.1080/ 13688790.2015.1191988

Schindler, S. (2016). School tracking, educational mobility and inequality in German secondary education: Developments across cohorts. European Societies, 19(1), 28-48. https://doi.org/10.1080/ 14616696.2016.1226373

Schroeter, S. (2009). Gender und Diversitaet. Kulturwissenschaftliche und Historische Annaeherungen [Gender and diversity. Cultural studies and historical approaches]. In S. Andresen, M. Koreuber, \& D. Lüdke (Eds.), Gender und Diversity: Albtraum oder Traumpaar? Interdisziplinärer Dialog zur "Modernisierung" von Geschlechter- und Gleichstellungspolitik [Gender and diversity: Nightmare or dream pair? Interdisciplinary dialogue regarding "modernization" of gender and equality politics] (pp. 79-94). VS Verlag für Sozialwissenschaften.

Spiess, C. K., \& Wrohlich, K. (2010). Does distance determine who attends a university in Germany? Economics of Education Review, 29(3), 470-479. https:// doi.org/10.1016/j.econedurev.2009.10.009

Stein, S. (2018). Beyond higher education as we know it: Gesturing towards decolonial horizons of possibility. Studies in Philosophy and Education, 38(2), 143-161. https://doi.org/10.1007/s11217-018-9622-7
Tamdgidi, M. H. (2012). Editor's note: To be of but not in the university. Human Architecture: Journal of the Sociology of Self-Knowledge, 10(1), 44-44. http://search.ebscohost.com/login.aspx?direct= true \&db=sih\&AN=70452064\&site=ehost-live

Tsvetkova, N. (2014). Making a new and pliable professor: American and Soviet transformations in German universities, 1945-1990. Minerva, 52(2), 161-185. https://doi.org/10.1007/s11024-014-9252-3

Unangst, L. (2020). Migrants, refugees, and "diversity" at German universities: A grounded theory analysis [Doctoral dissertation, Boston College]. ProQuest Dissertations and Theses Global. https://www. proquest.com/pqdtglobal/docview/2402547907/ 958DCC5B32A44F72PQ/17? accountid $=9673$

Verber, J. (2010). The conundrum of colonialism in postwar Germany. University of lowa Press.

Warikoo, N. K. (2016). The diversity bargain: And other dilemmas of race, admissions, and meritocracy at elite universities. University of Chicago Press.

Weber, S. (2016). 'Womanhood does not reside in documentation': Queer and Feminist student activism for Transgender women's inclusion at women's colleges. Journal of Lesbian Studies, 20(1), 29-45. https://doi. org/10.1080/10894160.2015.1076238

Wilkins, A. C. (2014). Race, age, and identity transformations in the transition from high school to college for Black and first-generation white men. Sociology of Education, 87(3), 171-187. https://doi.org/10.1177/ 0038040714537901

Winberg, S., \& Winberg, C. (2017, April). Using a social justice approach to decolonize an engineering curriculum. In 2017 IEEE Global Engineering Education Conference (pp. 248-254). IEEE.

Witte, A. (2011). Suspended between worlds? The discipline of Germanistik in sub-saharan Africa. In M. Perraudin \& J. Zimmerer (Eds.), German colonialism and national identity (pp. 292-303). Routledge.

Wolter, A. (2017). The expansion and structural change of postsecondary education in Germany. In P. G. Altbach, L. Reisberg, \& H. de Wit (Eds.), Responding to massification: Differentiation in postsecondary education worldwide (pp. 115-126). Sense Publishers.

Yao, C. W., George Mwangi, C. A., \& Malaney Brown, V. K. (2018). Exploring the intersection of transnationalism and critical race theory: A critical race analysis of international student experiences in the United States. Race Ethnicity and Education, 22(1), 38-58. https://doi.org/10.1080/13613324.2018.1497968

Zantop, S. (1997). Colonial fantasies: Conquest, family, and nation in precolonial Germany, 1770-1870. Duke University Press.

Zippel, K., Ferree, M. M., \& Zimmermann, K. (2016). Gender equality in German universities: Vernacularising the battle for the best brains. Gender and Education, 28(7), 867-885. https://doi.org/10.1080/09540253. 2015.1123229 


\section{About the Authors}

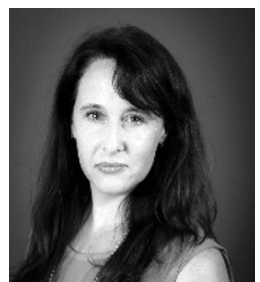

Lisa Unangst (PhD) is a Postdoctoral Researcher at the Centre for Higher Education Governance Ghent (CHEGG). Her research interests include how displaced learners access and experience higher education, as well as constructions of "diversity" policy. She has published in Comparative Education Review and Higher Education Policy, among other outlets. She also served as lead editor of the recent Brill-Sense publication Refugees and Higher Education: Trans-National Perspectives on Access, Equity, and Internationalization (2020).

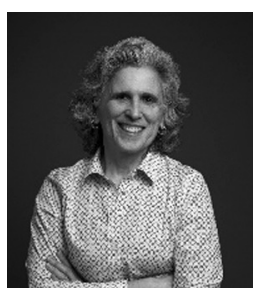

Ana M. Martínez Alemán (PhD) is Professor and Associate Dean for Faculty and Academics at the Lynch School of Education and Human Development. Her recent books include Critical Approaches to the Study of Higher Education (Johns Hopkins University Press, 2015), and Accountability, Pragmatic Aims, and the American University (Routledge, 2011). She is coauthor of Technology and Engagement: Making Technology Work for First Generation College Students (Rutgers University Press, 2018). 